\title{
Differential Localization of Phosphoinositide-linked Metabotropic Glutamate Receptor (mGluR1) and the Inositol 1,4,5-Trisphosphate Receptor in Rat Brain
}

\author{
Majid Fotuhi,' Alan H. Sharp,' Charles E. Glatt, ${ }^{1}$ Paul M. Hwang, ${ }^{1}$ Marcus von Krosigk, ${ }^{2}$ Solomon H. Snyder, ${ }^{1}$ \\ and Ted M. Dawson' \\ 'Departments of Neuroscience, Neurology Pharmacology and Molecular Sciences, and Psychiatry, The Johns Hopkins \\ University School of Medicine, Baltimore, Maryland 21205 and ${ }^{2}$ Section of Neurobiology, Yale University Medical School, \\ New Haven, Connecticut 06511
}

The type 1 metabotropic glutamate receptor (mGluR1) is thought to act via the phosphoinositide (PI) system with the associated formation of inositol 1,4,5-trisphosphate $\left(\mathrm{IP}_{3}\right)$ and $\mathrm{Ca}^{2+}$ release. Utilizing immunohistochemistry and in situ hybridization, we have localized protein and $M R N A$, respectively, for the mGluR1 and the $\mathbb{I P}_{3}$ receptor $\left(\mathbb{I P}_{3} R\right)$. We have also localized glutamate-linked $P I$ turnover by autoradiography with ${ }^{3} \mathrm{H}$-cytidine. We observe a striking contrast in localizations of mGluR 1 and $I P_{3} R$ both for protein and $m R N A$. For instance, mGluR1 occurs in the apparent absence of $\mathbb{P}_{3} R$ in neurons of the stratum oriens of the CA1 hippocampus, islands of Calleja, anterodorsal nucleus of thalamus, lateral nucleus of hypothalamus, and the granular cell layer and the deep nuclei of cerebellum. mGluR1 actions in these brain regions may primarily be mediated through the protein kinase $C$ limb of the PI system, as they contain moderate amounts of ${ }^{3} \mathrm{H}$-phorbol ester binding. The subthalamic nucleus, red nucleus, and Darkshevich's nucleus, which possess high levels of mGluR1, are devoid of both $\mathbf{I P}_{3} R$ immunoreactivity and ${ }^{3} \mathrm{H}$-phorbol ester binding. These reciprocal localizations suggest that mGluR1 actions in many brain areas may not primarily involve $\mathbb{I}_{3}$, reflecting instead influences on protein kinase $C$ or other second messengers.

[Key words: excitatory amino acid receptors, protein kinase $C$, phospholipase $C$, in situ hybridization, immunohistochemistry]

Glutamate, the major excitatory neurotransmitter in the brain, acts through two major classes of receptors (Mayer and Westbrook, 1987; Collingridge and Lester, 1989; Monaghan et al., 1989; Miller, 1991a,b). At ionotropic receptors, glutamate direclly opens ion channels. More recently, glutamate has been

Received July 6, 1992; revised Oct. 26, 1992; accepted Nov, 13, 1992.

This work was supported by U.S. Public Health Service Grant MH-18501, Research Scientist Award DA-00074 to S.H.S., a grant from the International Life Sciences Institute, and a gift of the Bristol-Myers-Squibb Company, Postdoctoral Fellowship MH-09953 to A.H.S., Predoctoral Fellowship MH-1001702 to C.E.G., and Training Grant GM-07309 to P.M.H. M.F. is supported in part by FCAR of Quebec, Canada. T.M.D. is a Pfizer Postdoctoral Fellow and is supported by the American Academy of Neurology and the French Foundation for Alzheimer's Research, the Dana Foundation, and U.S. Public Health Service CIDA NS 01578 01 .

Correspondence should be addressed to Solomon H. Snyder, Department of Neuroscience, The Johns Hopkins University School of Medicine, 725 North Wolfe Street, Baltimore, MD 21205.

Copyright (C) 1993 Society for Neuroscience $0270-6474 / 93 / 132001-12 \$ 05.00 / 0$ shown to act through a metabotropic glutamate receptor (mGluR) whereby phosphoinositide (PI) turnover is enhanced (for review, see Schoepp et al., 1990, Miller, 1991a; Baskys, 1992) via a G-protein mechanism (Nicoletti et al., 1988). Localizing neurotransmitter receptors provides valuable clues to their function. The ionotropic glutamate receptors have been localized by autoradiography with various ligands (for review, see Monaghan et al., 1989; Young and Fagg, 1990). Such localization has not been feasible for $\mathrm{mGluR}$ because of the lack of suitable ligands. Recently, we developed a technique to visualize PI turnover in brain slices utilizing ${ }^{3} \mathrm{H}$-cytidine as a precursor to the PI cycle and could demonstrate selective enhancement in discrete brain structures by glutamate derivatives (Hwang et al., 1990a). However, the limited resolution of this technique has precluded detailed analysis of mGluR localizations. mGluR has been molecularly cloned (Houamed et al., 1991; Masu et al., 1991) and four subtypes identified (Tanabe et al., 1992). mGluR1 is PI linked, and alternative splicing yields a long and short form designated $\mathrm{mGluR} 1 \alpha$ and $\mathrm{mGluR} 1 \beta$, respectively. In addition, mGluR1 receptor stimulation leads to increased cAMP formation and release of arachidonic acid (Aramori and Nakinishi, 1992), mGluR2 activation inhibits forskolin-induced cAMP formations, while mGluR3 and mGluR4 have no known function (Tanabe et al., 1992). Recently, another mGluR coupled to PI hydrolysis, designated mGluR5, has been cloned (Abc ct al., 1992).

Utilizing an antiserum generated against peptides from the mGluR1 amino acid sequence and four oligonucleotides derived from the mGluR 1 cDNA that specifically recognize mGluR $1 \alpha$ and $\mathrm{mGluR} 1 \beta$, we have conducted immunohistochemical and in situ hybridization localization of mGluR 1 protein and mRNA, respectively. We now report a striking contrast in the brain localizations of mGluR 1 compared to PI turnover and inositol 1,4,5-trisphosphate receptor $\left(\mathrm{IP}_{3} \mathrm{R}\right)$ protein and mRNA.

\section{Materials and Methods}

Materials. The Vectastain immunohistochemistry kit was purchased from Vector. ${ }^{3} \mathrm{H}$-cytidine $(27.8 \mathrm{Ci} / \mathrm{mmol})$ was obtained from New England Nuclear/Du Pont. All other materials were purchased from Sigma, unless otherwise specified.

Preparation of anti-mGluR1 antiserum. A synthetic peptide based on amino acids 141-154 of mGluR 1 protein (Masu et al., 1991) was madc and conjugated to bovine serum albumin (BSA). To ensure selective coupling through one of the carboxyl terminal lysine residues, the amino terminus of the peptide was first blocked by reaction of the peptide at $\mathrm{pH} 7.4$ with a twofold molar excess of citraconic anhydride for $3 \mathrm{hr}$ at 
room temperature. BSA was then added to the peptide, to a ratio of approximately 1 BSA molecule per 10 peptide molecules, followed by addition of glutaraldehyde (final concentration, $0.1 \%$ ) for $1 \mathrm{hr}$ at room temperature. The conjugation reaction was stopped by incubation with excess glycine for $1 \mathrm{hr}$ at room temperature. The conjugate was dialyzed first against $100 \mathrm{~mm}$ sodium acetate, $\mathrm{pH} \mathrm{4.2,} \mathrm{for} 5 \mathrm{hr}$ and then against phosphate-buffered saline (PBS) overnight. Antiserum was raised in rabbits injected with the above BSA-conjugated peptide (Cocalico Biologicals, Inc., Reamstown, PA).

Antiserum solution was purified at three steps. First, it was adsorbed overnight, at $4^{\circ} \mathrm{C}$, with an affinity matrix consisting of proteins extracted from crude brain membrane using high $\mathrm{pH}(\mathrm{NaOH}$ extract) and immobilized on cyanogen bromide $(\mathrm{CNBr})$-activated Sepharose. Preliminary results showed that the mGluR 1 protein adheres to a heparinagarose column (A. H. Sharp, T. M. Dawson, and S. H. Snyder, unpublished observations). Thus, the antiserum solution was further absorbed with an affinity matrix consisting of Triton X-100-solubilized cerebellar membranes that had been passed through a heparin-agarose column before immobilization on CNBr-activated Sepharose. Finally, it was affinity purified using a column consisting of an ovalbuminmGluR 1 peptide conjugate immobilized on $\mathrm{CNBr}$-activated Sepharose, batchwise, overnight at $4^{\circ} \mathrm{C}$. The antiserum was eluted from the column with $4 \mathrm{M} \mathrm{MgCl}_{2}$, dialyzed first against PBS and then against PBS containing $20 \%$ sucrose, and stored in small aliquots at $-70^{\circ} \mathrm{C}$ until use. $I P_{3} R$ goat affinity-purified antiserum was produced as described previously (Peng et al., 1991; Sharp et al., 1993).

Western blot analysis. Particulate fractions from different brain regions were prepared in $50 \mathrm{~mm}$ Tris $\mathrm{HCl}$ buffer containing $1 \mathrm{~mm}$ EDTA, 0.5 nM phenylmethysulfonyl fluoride, and $1 \mathrm{~mm}$ benzamidine. Proteins $(150$ $\mu \mathrm{g}$ per lane) were separated on a $7.5 \%$ SDS polyacrylamide gel, transferred to Immobilon-P membranes (Millipore), and probed with affinity-purified antibody (1:100) overnight. Blots were then washed and incubated with peroxidase-linked goat anti-rabbit secondary antibody (1:1500; Boehringer Mannheim) for $2 \mathrm{hr}$ at room temperature. Bands were visualized using the chromogen 4-chloro-1-naphthol (ImmunoSELECT). For preadsorption experiments performed on fractions of different brain regions, antibody was preincubated with 20 -fold excess of peptide antigen for $24 \mathrm{hr}$ at $4^{\circ} \mathrm{C}$.

Immunohistochemistry. Adult male Sprague-Dawley rats were perfused with $2-4 \%$ freshly depolymerized paraformaldehyde in $50 \mathrm{~mm}$ PBS. Brains were removed and postfixed for $2 \mathrm{hr}$ in $2-4 \%$ paraformaldehyde followed by cryoprotection in $20 \%$ glycerol overnight. Sections were cut $(40 \mu \mathrm{m})$ on a sliding microtome and transferred to $50 \mathrm{~mm}$ Tris $\mathrm{HCl}$-buffered saline (TBS). They were permeabilized in $0.4 \%$ Triton $\mathrm{X}-100$ for $30 \mathrm{~min}$, blocked in $10 \%$ normal goat serum for $1 \mathrm{hr}$, and incubated in primary affinity-purified mGluR 1 antibody $(1: 1000)$ or affinity-purified $I P_{3} R$ antibody (1:1000) (Peng et al., 1991) overnight. Immunostaining was visualized with an avidin-biotin kit (Vectastain $\mathrm{ABC} \mathrm{Kit})$ in which diaminobenzidine was the chromogen.

In situ hybridization. A pool of four antisense oligonucleotide probes, complementary to nucleotides 1779-1827, 2067-2103,2181-2229, and 2472-2520 of the cloned mGluR 1 cDNA (Masu et al., 1991), and a pool of three complementary oligonucleotide probes to nucleotides 1077$1125,327-375$, and $1452-1500$ of the cloned $I_{3} R$ cDNA (Nordquist ct al, 1988), were end labeled with ${ }^{35} \mathrm{~S}-\gamma$-ATP and terminal transferase (Bethesda Research Labs). In situ hybridization was carried out exactly as described previously (Ross et al., 1989). Briefly, 12- $\mu \mathrm{m}$-thick brain sections were dehydrated, defatted, and then incubated with $1 \times 10^{6}$ cpm probe per $100 \mu \mathrm{l}$ formamide hybridization buffer ( $50 \%$ formamide, $1 \times$ Denhardt's solution, $10 \mathrm{~mm}$ sodium phosphate $\mathrm{pH} 7.4,1 \mathrm{~mm}$ EDTA, $100 \mu \mathrm{g} / \mathrm{ml}$ salmon sperm DNA, $100 \mu \mathrm{g} / \mathrm{ml}$ tRN.A, $10 \%$ dextran sulfate, and $10 \mathrm{~mm}$ dithiothreitol) over $24 \mathrm{hr}$ at $37^{\circ} \mathrm{C}$. Sections were washed first for $15 \mathrm{~min}$ at room temperature and then for $1 \mathrm{hr}$ at $55^{\circ} \mathrm{C}$ in $1 \times$ saline-sodium citrate buffer containing $0.1 \% \beta$-mercaptoethanol, briefly dipped in $\mathrm{H}_{2} \mathrm{O}$, and dried. Sections were exposed to Beta-Max film (Amersham) or dipped in Kodak NTB2 emulsion $\left(1: 1\right.$ with $\left.\mathrm{H}_{2} \mathrm{O}\right)$ and allowed to expose for $1-3$ weeks at $-70^{\circ} \mathrm{C}$. Each individual probe gave identical distributions in the brain to other probes in that pool (data not shown).

Electron microscopy. Adult male Long-Evans Hooded and SpragueDawley rats (150-300 gm) were used for immunoelectron microscopic analysis. The animals were given a lethal dose of anesthetic and perfused transcardially with cold, oxygenated $\left(95 \% \mathrm{O}_{2}, 5 \% \mathrm{CO}_{2}\right)$ artificial cerebrospinal fluid (126 m NaCl, $2.5 \mathrm{~mm} \mathrm{KCl}, 1.25 \mathrm{~mm} \mathrm{NaH} \mathrm{PO}_{4}, 2 \mathrm{~mm}$ $\mathrm{MgSO}_{4}, 26 \mathrm{mM} \mathrm{NaHCO}_{3}$ ) and immediately followed by $500 \mathrm{ml}$ of cold fixative [ $4 \%$ paraformaldehyde, $0.05 \%$ glutaraldehyde in $0.1 \mathrm{M}$ phosphate buffer (PB) $\mathrm{pH}$ 7.4]. The brains were removed and placed into the fixative solution overnight before being cut into blocks and sectioned to $50 \mu \mathrm{m}$ on a vibrating microtome. The sections containing the striatum were placed into a cryoprotecting solution consisting of $25 \%$ sucrose and $5 \%$ glycerol in $50 \mathrm{~mm} \mathrm{~PB} \mathrm{(pH} \mathrm{7.4).} \mathrm{Once} \mathrm{the} \mathrm{sections} \mathrm{had} \mathrm{sunk} \mathrm{in}$ the cryoprotectant, they were freeze thawed in isopentane that had been chilled in liquid nitrogen.

The immunohistochemical procedure was carried out as above. Sections were then rinsed in phosphate buffer ( $\mathrm{pH} 7.4)$ and postfixed in $1 \%$ osmium tetroxide for $30 \mathrm{~min}$. They were then briefly rinsed in TBS before being incubated in a $2 \%$ uranyl acetate solution (aq) for 45-60 min. Following this, they were dehydrated through a graded series of alcohol, followed by propylene oxide prior to embedding in resin (Durcupan ACM, Fluka). Sections were placed in Durcopan overnight before bcing flat embedded between two silicon-coated (Sigmacote, Sigma) glass slides. The resin was then polymerized at $60^{\circ} \mathrm{C}$ for $48 \mathrm{hr}$. After light microscopic analysis, areas of the striatal matrix regions were selected and cut out from the slides and reembedded in blocks for further sectioning. These blocks were then sectioned for electron microscopy on a ultramicrotome and collected on either copper mesh grids or Pioloform-coated copper slot grids. The ultrathin sections were then examined with a JEOL $100 \mathrm{~S}$ electron microscope, with some grids being stained with lead citrate.

Phosphoinositide (PI) turnover and imaging. Regions of rat brain corresponding to those areas in the regional Western blot analysis were rapidly dissected and cross-chopped into $400 \mu \mathrm{m}$ pieces of tissue. The cross-chopped tissue was first allowed to recover for $30 \mathrm{~min}$ in Krebsbicarbonate buffer followed by incubating $(50 \mu \mathrm{l}$ of gravity-picked tissue $)$ in $250 \mu$ l of Krebs-bicarbonate buffer containing $0.1 \mu \mathrm{Ci} / \mathrm{ml}^{3} \mathrm{H}$-cytidine (Du Pont/New England Nuclear; $27.8 \mathrm{Ci} / \mathrm{mmol}$ ) in an interface chamber $\left(95 \% \mathrm{O}_{2}, 5 \% \mathrm{CO}_{2}\right)$ at $37^{\circ} \mathrm{C}$. $\mathrm{LiCl}$ (final concentration, $5 \mathrm{~mm}$ ) was subsequently added followed $10 \mathrm{~min}$ later by $300 \mu \mathrm{M}$ trans-1-aminocyclopentane-1,3-dicarboxylate (t-ACPD). After $1 \mathrm{hr}$ of incubation at $37^{\circ} \mathrm{C}$, the reaction was stopped on ice, membranes were lipid extracted, and the amount of radioactivity, that is, ${ }^{3} \mathrm{H}$-cytidine diphosphate diacylglycerol ( $\left.{ }^{3} \mathrm{H}-\mathrm{CDP}-\mathrm{DAG}\right)$ accumulation, was determined using a scintillation counter (Godfrey, 1989).

The steps in PI imaging are similar and were carried out exactly as described (Hwang et al., 1990a). Briefly, rat brain slices $(400 \mu \mathrm{m})$ of olfactory bulb, hippocampus, or cerebellum were allowed to recover for $1 \mathrm{hr}$ at $20^{\circ} \mathrm{C}$ in an interface chamber $\left(95 \% \mathrm{O}_{2}, 5 \% \mathrm{CO}_{2}\right)$. They were prelabeled on Whatman filter paper circles $(2.1 \mathrm{~cm}$ in diameter) that were immersed in $0.1 \mathrm{ml}$ of Krebs-bicarbonate buffer (on upside-down covers of 24-well tissue culture plates) containing $4.0 \mu \mathrm{Ci} / \mathrm{ml}{ }^{3} \mathrm{H}$-cytidine (Du Pont/New England Nuclear; $27.8 \mathrm{Ci} / \mathrm{mmol}$ ), $1 \mu \mathrm{g} / \mathrm{ml}$ actinomycin (Boehringer Mannheim), and $50 \mu \mathrm{M}$ hydroxyurea (Sigma) for $\mathrm{l} \mathrm{hr}$ at $30^{\circ} \mathrm{C}$. $\mathrm{LiCl}(5 \mathrm{~mm}$ final concentration) was added beneath the Whatman filter paper with tissue on top 10 min prior to addition of $100-300 \mu \mathrm{M}$ $\mathrm{t}$-ACPD in order to allow even diffusion of $\mathrm{LiCl}$. Following $50-60 \mathrm{~min}$ of incubation at $37^{\circ} \mathrm{C}$, sections were transferred to plastic molds and embedded in 0.C.T. medium (Tissue-Tek). Frozen sections were cut (16 $\mu \mathrm{m})$ on gelatin-coated glass slides, treated in wash buffer $(50 \mathrm{~mm}$ Tris $\mathrm{HCl} \mathrm{pH} \mathrm{4.2,2} \mathrm{mм} \mathrm{EDTA,} 10 \mathrm{~mm} \mathrm{LiCl}, 1 \mathrm{~mm}$ cytidine, $3 \%$ polyethylene glycol, $0.005 \%$ saponin, $20 \mu \mathrm{g} / \mathrm{ml}$ each of RNase A and DNase I) for $2-5 \mathrm{~min}$ at $37^{\circ} \mathrm{C}$, quickly dried, and apposed to film (Hyperfilm $-{ }^{3} \mathrm{H}$, Amersham) or Kodak NTB emulsion-coated coverslips for 2-4 weeks.

\section{Results}

mGluRI protein levels and ACPD-stimulated PI turnover differ in brain regions. A rabbit polyclonal antiserum corresponding to the peptides 141-154 of the N-terminal region of mGluR1 (Masu et al., 1991) was developed. It recognizes mGluR1 by Western blot analysis. Interestingly, two immunoreactive bands are identified at about $140 \mathrm{kDa}$ and $100 \mathrm{kDa}$, in all brain regions (Fig. 1). Preadsorption of the antiserum with excess peptide antigen completely eliminated staining, in cerebellum and other brain rcgions (data not shown) (Fig. 1). These bands correspond to the predicted molecular weights of the cloned mGluR $1 \alpha$ and mGluR $1 \beta$, respectively (Tanabe et al., 1992). The relative abundance of $\mathrm{mGluR} 1 \alpha$ and $\mathrm{mGluR} 1 \beta$ differ in brain regions, with 
mGluR $1 \alpha$ predominating in the cerebellum and olfactory bulb and $\mathrm{mGluR} 1 \beta$ as the major form in other areas.

To assess the relationship between the amount of mGluR 1 immunoreactivity and glutamate-mediated PI turnover, we measured $t$-ACPD (a selective ligand for the mGluR1)-stimulated PI turnover in various brain regions and conducted Western blot analysis of mGluR 1 protein in the same brain regions (Fig. 1). We detect t-ACPD-elicited PI turnover in all regions containing mGluR 1 protein. However, the relative intensity of mGluR 1 staining is dissociated from the relative amount of t-ACPD-stimulated PI turnover. For instance, highest levels of mGluR 1 protein are found in the cerebellum, which contains only moderate levels of t-ACPD-stimulated PI turnover (Fig. 1).

$m$ GluRI localizations differ from those of $I P_{3} R m R N A$ and protein. The PI cycle involves receptor-mediated stimulation of phospholipase C (PLC) activity generating diacylglycerol (DAG), which stimulates protein kinase $\mathrm{C}(\mathrm{PKC})$ activity, and $\mathrm{IP}_{3}$, which binds to the $\mathrm{IP}_{3} \mathrm{R}$ to evoke calcium release (Berridge and Irvine, 1989; Ferris and Snyder, 1992). Localizations for protein and mRNA of PLC (Gerfen et al., 1988; Ross et al., 1989), PKC (Worley et al., 1986a,b, 1987; Huang et al., 1988; Saito ct al., 1988; Yoshihara et al., 1991), and $\mathrm{IP}_{3} \mathrm{R}$ (Worley et al., 1989; Nakagawa et al., 1991a,b; Nakanishi et al., 1991) are closely similar, though not identical (Worley et al., 1987). There are also some differences in the disposition of subtypes of PLC (Gerfen et al., 1988; Ross et al., 1989) and PKC (Yoshihara et al., 1991). Only one major form of $\mathrm{IP}_{3} \mathrm{R}$ has been identified by protein purification and molecular cloning, though alternatively spliced forms of this $I_{3}$ R exist (Danoff et al., 1991; Nakagawa et al., $1991 \mathrm{a}, \mathrm{b})$ and recently quantitatively minor forms of distinct subtypes of $\mathrm{IP}_{3} \mathrm{R}$ derived from different genes have been identified (Südhof et al., 1991; Ross et al., 1992). Because the distribution of the quantitatively major, first isolated form of the $\mathrm{IP}_{3} \mathrm{R}$ resembles other markers of the PI cycle, we have compared its localization to that of mGluR1. If mGluR1 is coupled to PI turnover, one would anticipate close similarities between the distribution of mGluR1 and $\mathrm{IP}_{3} \mathrm{R}$.

In numerous areas, the localizations of mGluR 1 and $\mathrm{IP}_{3} \mathrm{R}$ protein and mRNA differ strikingly (Figs. 2-5, Table 1; see also Fig. 8). For instance, in the cerebellum $\mathrm{IP}_{3} \mathrm{R}$ mRNA and protein are exclusively localized to Purkinje cells and their processes, while mGluR1 occurs both in Purkinje cells and granule cells. mGluR I mRNA is highly concentrated in deep cerebellar nuclei that are devoid of $I_{3} R$ mRNA (Fig. 2). IP $_{3} R$ protein occurs in Purkinje cell terminals synapsing upon deep cerebellar nuclei, whereas $\mathrm{mGluR} 1$ protein is apparent within perikarya of these nuclei (data not shown).

$\mathrm{IP}_{3} \mathrm{R}$ protein and mRNA are concentrated within pyramidal cells of all regions and lamina of the cerebral cortex (Figs. 25). In contrast, mGluR 1 mRNA is confined to occasional nonpyramidal neurons throughout the cortex (Fig. $5 C$ ). Substantial mGluR 1 protein is evident within the cortical neuropil, apparently reflecting terminal patterns that may arise from the thalamus, where mGluR1 mRNA and protein levels are high.

In the hippocampus, $\mathrm{IP}_{3} \mathrm{R}$ and $\mathrm{mGluR} 1$ protein and $\mathrm{mRNA}$ (Figs. 2-4, 6) display notably reciprocal localizations. $\mathrm{IP}_{3} \mathrm{R}$ is concentrated in a dense band comprising the CAl pyramidal layer with much lower levels in CA3, whereas mGluR1 is enriched in CA3 with low levels in CA1. mGluR1 immunoreactivity is concentrated in fine fibers in the stratum oriens of CAl and the subiculum, where staining for $\mathrm{IP}_{3} \mathrm{R}$ is minimal (Fig. 6,
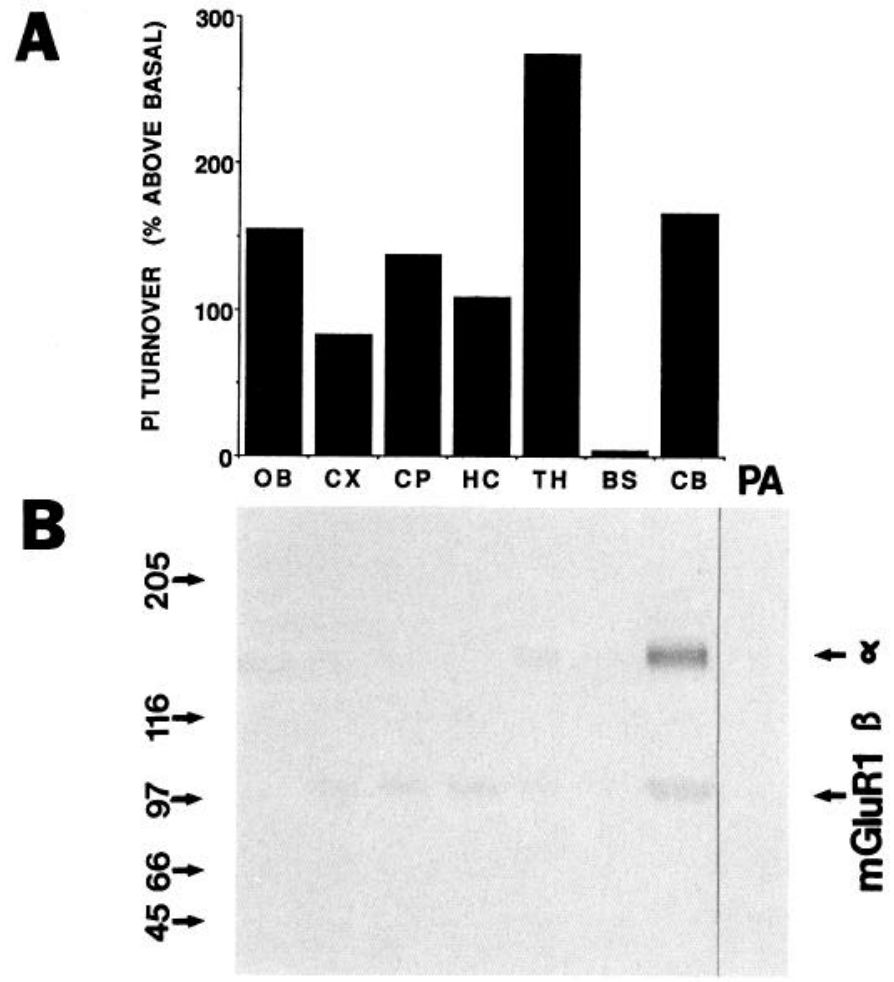

Figure 1. Regional distribution of PI turnover and mGluR1 protein in brain. PI turnover $(A)$ and Western blot analysis $(B)$ experiments were carried out as described in Materials and Methods. t-ACPD-stimulated PI turnover represents the mean of two to four experiments performed in triplicate in which the results varied less than $10 \%$. Control levels of ${ }^{3} \mathrm{H}$-CDP-DAG were consistently approximately $100 \mathrm{cpm} / 50$ $\mathrm{mg}$ tissue. Preadsorption $(P A)$ with excess peptide completely attenuates the cerebellar immunoreactive band observed on Western blot analysis. $O B$, olfactory bulb; $C X$, cortex; $C P$, caudate-putamen; $H C$, hippocampus; $T H$, thalamus-hypothalamus; $B S$, brainstem; $C B$, cerebellum.

Table 1; see also Fig. 9). The molecular layer of the dentate gyrus displays very low levels of $\mathrm{IP}_{3} \mathrm{R}$ but high levels of mGluR1. In contrast, the granule cell layer of dentate gyrus exhibits high $\mathrm{IP}_{3} \mathrm{R}$ and low mGluR 1 levels.

The olfactory bulb provides further evidence for a dissociation between mGluR 1 and $\mathrm{IP}_{3} \mathrm{R}$ mRNA and protein (Figs. 24, 7; Table 1; see also Fig. 9). Substantial levels of mGluR1 protein occur in the glomeruli, external plexiform, and mitral cells of the olfactory bulb, while $\mathrm{IP}_{3} \mathrm{R}$ is concentrated within the periglomerular and granule cells with moderate levels in tufted cells (Fig. 7A,B).

Divergent patterns in the thalamus (Figs. 2-4, Table 1) are evident for $\mathrm{mGluR}_{1}$ and $\mathrm{IP}_{3} \mathrm{R} \mathrm{mRNA}$ and protein. In contrast to high mGluR1 levels, $\mathrm{IP}_{3} \mathrm{R}$ levels are much lower in most of the thalamus. The anterior dorsal thalamic nucleus contains abundant mGluR1 but no $\mathrm{IP}_{3} \mathrm{R}$ at all. The anterior ventral nucleus and the ventral lateral posterior nucleus are enriched in mGluR1 with low levels of $\mathrm{IP}_{3} \mathrm{R}$. The medial and lateral geniculate nuclei contain high levels of mGluR 1 , but only low to moderate levels of $\mathrm{IP}_{3} \mathrm{R}$ (Fig. 4). Similarly, the gelatinosum nucleus and subthalamic nucleus are enriched in mGluR 1 but lack substantial staining for $\mathrm{IP}_{3} \mathrm{R}$. In the hypothalamus, dramatic reciprocity of $m$ GluR 1 and $I P_{3} R$ is evident in the lateral hypothalamic nucleus with high levels of $\mathrm{mGluR} 1$ but no $\mathrm{IP}_{3} R$ (Figs. 4, $7 E, F)$. By contrast, the dorsal medial hypothalamic 


\section{MGIuR}

A

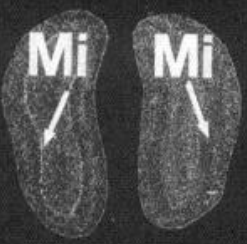

B
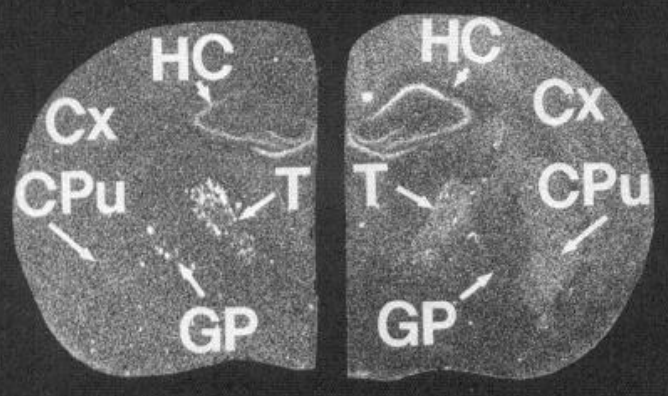

E

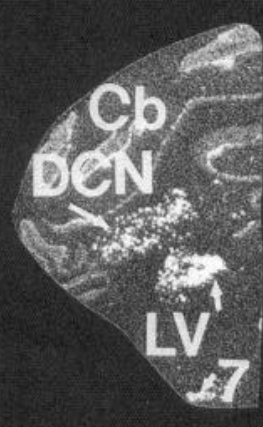

$\mathbf{F}$
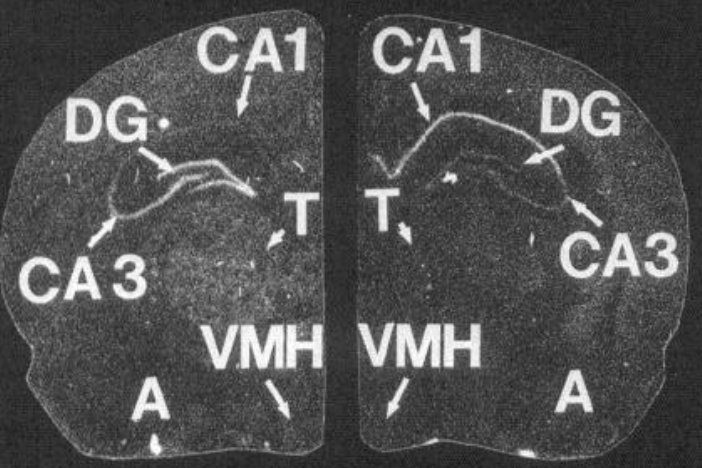
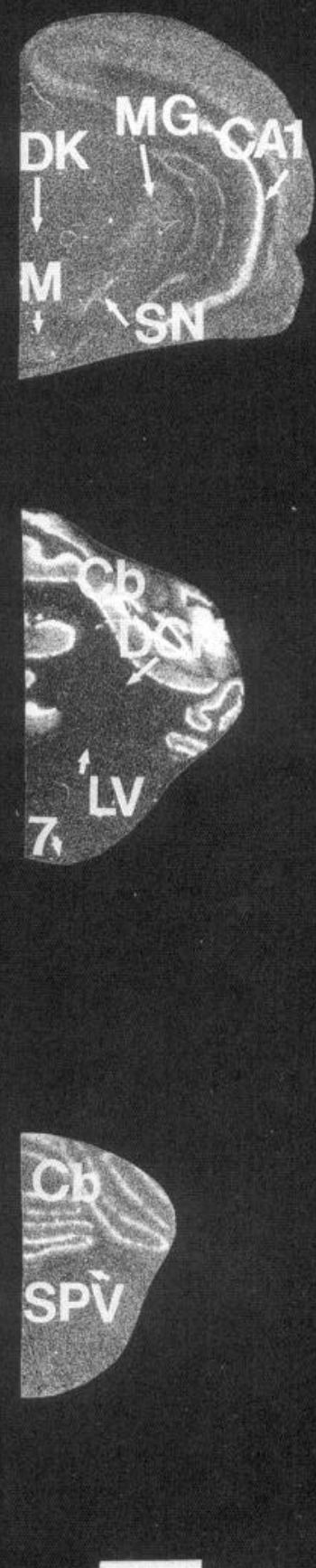

Figure 2. Comparison of the localization of mGluR1 $(\alpha$ and $\beta)$ and $\mathrm{IP}_{3} \mathrm{R}$ mRNAs. Pairs of adjacent thin $(12 \mu \mathrm{m})$ sections of rat brain were processed for in situ hybridizations with ${ }^{35}$ S-labeled oligonucleotides specific for mGluR1 (left) and IP ${ }_{3} \mathrm{R}$ (right) cDNAs. Labeled structures appear white in these dark-field images. The relatively higher level of mGluRl versus $\mathrm{IP}_{3} \mathrm{R}$ labeling is evident in the mitral layer $(\mathrm{Mi})$ of the olfactory bulb, $C A 3$ region of hippocampus $(H C)$, dentate gyrus $(D G)$, globus pallidus $(G P)$, thalamic nuclei $(T)$ including medial geniculate nucleus $(M G)$, and in the mammillary bodies $(M)$. mGluR1 labeling also occurs in apparent absence of $\mathrm{IP}_{3} \mathrm{R}$ labeling in the Darkshevich's nucleus $(D K)$, deep cerebellar nuclei $(D C N)$, lateral vestibular nucleus $(L V)$, facial nucleus (7), and spinal motor nucleus of the trigeminal nerve $(S P V)$. Conversely, higher amounts of $\mathrm{IP}_{3} \mathrm{R}$ labeling appear in cortex $(C x)$, caudate-putamen $(C P u), C A 1$ region of hippocampus, upper layer (pars compacta) of substantia nigra $(S N)$, and Purkinje layer of cerebellum $(C b)$. Amygdala $(A)$ and ventral medial nucleus of hypothalamus $(V M H)$ contains low levels of labeling for both mGluR1 and $\mathrm{IP}_{3} \mathrm{R}$. Scale bar, $100 \mu \mathrm{m}$. 
nucleus displays abundant $\mathrm{IP}_{3} \mathrm{R}$ with negligible $\mathrm{mGluR} 1$ (data not shown).

The striatum possesses low levels of mGluRl mRNA but high levels of $\mathrm{IP}_{3} \mathrm{R}$ mRNA (Fig. 2). However, both mGluR 1 and $I P_{3} R$ proteins are abundant (Figs. 3, 4). $I P_{3} R$ is primarily localized to perikarya and dendrites of medium spiny neurons (Figs. 3, 4, 8) and is enriched within the striosomal compartment (Fotuhi et al., 1991). In contrast, mGluR1 is enriched in the presynaptic terminal fields in neuropil within the matrix compartment, although occasional postsynaptic neurons stain for mGluR 1 (Figs. 3, 8, and data nol shown). The nearby islands of Calleja are enriched in mGluR 1 with no $\mathrm{IP}_{3} R$, whereas the surrounding olfactory tubercle contains abundant $\mathrm{IP}_{3} \mathrm{R}$ but is devoid of mGluR1 (Figs. 4, 7C,D).

The substantia nigra pars compacta contains low mGluR1 but high $\mathrm{IP}_{3} \mathrm{R}$ mRNA and protein (Figs. 2-4) in neurons with a pattern characteristic of dopamine-containing cell bodies. Within the substantia nigra pars reticulata, both mGluR $1 \mathrm{mRNA}$ and protein are present. In contrast, $\mathrm{IP}_{3} \mathrm{R}$ mRNA is absent in pars reticulata, but $I_{3} R$ protcin is enriched, apparently reflecting terminal patterns from striatal projection neurons.

In the brainstem and midbrain regions (Figs. 2-4, Table 1) striking differences in $\mathrm{mGluRI}$ and $\mathrm{IP}_{3} \mathrm{R}$ dispositions are evident in the nucleus of Darkshevich, the lateral vestibular nuclei, the red nucleus, and the cranial nerve nuclei. mGluR 1 mRNA and protein are highly enriched in these structures, but $I_{3} R$ mRNA and protein are virtually absent (Figs. $2 E, F ; 4)$. The superior colliculus contains high levels of mGluR 1 protein, but only moderate levels of $I_{3} R$. In contrast, the pontine nuclei are enriched in $\mathrm{IP}_{3} \mathrm{R}$ but low in mGluRI (Fig. 3).

Electron microscopy reveals dissociation of $m G l u R I$ and $I P_{3} R$ at the ultrastructural level. In the striatum, mGluR 1 is primarily localized to presynaptic terminals (Fig. 8), although occasional postsynaptic densities do occur (data not shown). In contrast, ${ }_{I} P_{3} R$ immunoreactivity is predominantly enriched in all postsynaptic structures. These include somata, dendritic shafts, and spines (Fig. 8).

Dissociation of $m G l u R I$ protein from $I P_{3} R$ protein and $t$-ACPD-stimulated PI turnover. To explore further the dissociation of $m G l u R 1$ and $I_{3} R$ proteins, we compared the anatomical distribution of $m$ GluR 1 and $I P_{3} R$ proteins with $t-A C P D-$ stimulated PI turnover in tissue slices (Fig. 9). In the olfactory bulb, both t-ACPD-stimulated PI turnover and mGluR 1 immunoreactivity are concentrated within the glomeruli. In con- trast, $I_{3} R$ is concentrated in periglomerular cells (Figs. 7, 9). The hippocampus displays striking differences between $t-A C P D-$ elicited PI turnover, mGluR1, and $\mathrm{IP}_{3} \mathrm{R}$ protein (Fig. 9). Both $t$-ACPD-stimulated PI turnover and mGluR 1 are enriched in CA3 with low levels of $I P_{3} R$. In contrast, mGluR1 protein is abundant within the molecular layer of the dentate gyrus, where

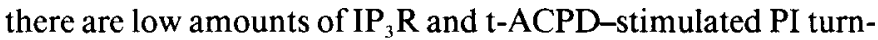

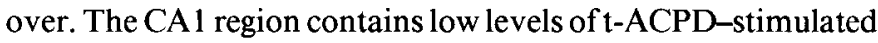
PI turnover, which might reflect mGluR1 within the stratum oriens. In the cerebellum all three markers are enriched within the molecular layer. However, there is virtually no t-ACPDstimulated PI turnover in the deep cerebellar nuclei, where both $\mathrm{IP}_{3} \mathrm{R}$ and $\mathrm{mGluR} 1$ proteins are present in high concentrations.

\section{Discussion}

mGluR1 is distributed distinctly throughout all regions of the brain, with highest levels in the olfactory bulb, CA3 and the dentate gyrus of the hippocampal formation, the thalamus, lateral hypothalamus, cranial nuclei of the brainstem, and the cerebellum. mGluR 1 immunoreactivity in some areas (e.g., lateral hypothalamus) is limited to neuronal perikarya, while in other areas it is enriched in the neuropil (e.g., cerebral cortex).

Our antibody apparently recognizes both the long and short forms of mGluR $1, \mathrm{mGluR} 1 \alpha$, and mGluR $1 \beta$, respectively. It is not known whether mGluR $1 \beta$ is a functional receptor (Tanabe et al., 1992), but the identification of a protein of appropriate molecular weight $(100 \mathrm{kDa})$ by our antibody suggests that mGluR $1 \beta$ is expressed in several brain regions. The anatomical distribution of our antibody is much more extensive, although completely inclusive of the distribution of an antibody specific for mGluR $1 \alpha$ (Martin et al., 1992). Presumably, the immunostaining shown here represents both mGluR $1 \alpha$ and mGluR $1 \beta$ as staining is completely blocked by preadsorption with excess peptide. Interestingly, Western blot analysis reveals differences between the distribution of $\mathrm{mGluR} 1 \alpha$ and $\mathrm{mGluR} 1 \beta$. mGluR $1 \alpha$ is present in the olfactory bulb and is present in high amounts in the thalamus, and cerebellum, while mGluR $1 \beta$ is enriched in the cortex, caudate-putamen, and hippocampus as well as in the olfactory bulb, thalamus, and cerebellum (Fig. 1). mGluR $1 \beta$ may be located primarily presynaptically, as our electron microscopy in the striatum shows a predominant presynaptic labeling pattern and the Western blot analysis demonstrates that the striatum contains very low levels of mGluR $1 \alpha$. Consistent with mGluR1 immunoreactivity primarily limited to presyn-

\footnotetext{
Figure 3. Immunohistochemical localization of $\mathrm{mGluR} 1$ and $\mathrm{IP}_{3} \mathrm{R}$ proteins in sagittal brain sections. Adjacent thick (40 $\left.\mu \mathrm{m}\right)$ rat sagittal brain sections were stained with affinity-purified antibodies against mGluR1 $(\alpha$ and $\beta)(A)$ and $\mathrm{IP}_{3} \mathrm{R}(B)$. $C$, Preadsorption $(P A)$ of antibodies against mGluR I with its respective antigen completely abolishes immunostaining; similar results were obtained with the $I P_{3} R$ antibody (data not shown). Immunoreactive structures appear white in these dark-field images. Areas high in mGluR 1 immunoreactivity but low in $I P_{3} R$ immunoreactivity include olfactory bulb $(O B), C A 3$ of the hippocampus, dentate gyrus $(D G)$, thalamus $(T)$, granular layer of cerebellum $(C b)$, superior colliculus $(S C)$, and lateral hypothalamus $(L H)$. Areas low in $\mathrm{mGluR} 1$ and high in $\mathrm{IP}_{3} \mathrm{R}$ immunostaining include the anterior olfactory nucleus $(A O)$, olfactory tubercle $(T u)$, pyramidal cell layer of cortex $(C x)$, caudate-putamen $(C P)$, and pontine nucleus $(P n)$. $S N$, substantia nigra. Scale bar, 2.5 mm.

Figure 4. Contrasting localization of $\mathrm{mGluRl}$ and $\mathrm{IP}_{3} \mathrm{~K}$ immunoreactivity in coronal brain sections. Pairs of adjacent thick (40 $\left.\mu \mathrm{m}\right)$ coronal rat brain sections were immunohistochemically processed with affinity-purified mGluR1 (left) and $\mathrm{IP}_{3} \mathrm{R}$ (right) antibodies. Positive staining appears white in these dark-field images. The contrasting distributions of these two proteins revealed by in situ hybridization in Figure 2 is more clearly apparent in these immunostained sections. Much higher amounts of mGluRl staining are present in the olfactory bulb $(O B)$ and in the following thalamic nuclei: anterodorsal $(A D)$, anteroventral $(A V)$, ventrolateral posterior $(V P L)$, medial geniculate $(M G)$, and nucleus gelatinosum $(G)$. The lateral hypothalamus $(L H)$, islands of Calleja $(I C j)$, mammillary bodies $(M)$, and nucleus of Darkshevich $(D K)$ also exhibit more mGluR 1 than IP, $R$ immunoreactivity. Similarly, in the brainstem, many of the cranial nuclei including the motor nucleus of the trigeminal nerve (5) as well as the substantia gelatinosa and ventral horn of spinal cord $(S c)$ contain higher amounts of $m G l u R l$ immunoreactivity. Areas with higher $I P_{3} R$ immunorcactivity depicted in these sections include the internal capsule (ic), $C A l$ of hippocampus, pars reticulata (the lower portion) of substantia nigra $(S N)$, and Purkinje cell layer of cerebellum $(C b) . D G$, dentate gyrus; $C P$, caudate-putamen; $C x$, cortex. Scale bar, $2.5 \mathrm{~mm}$.
} 
A

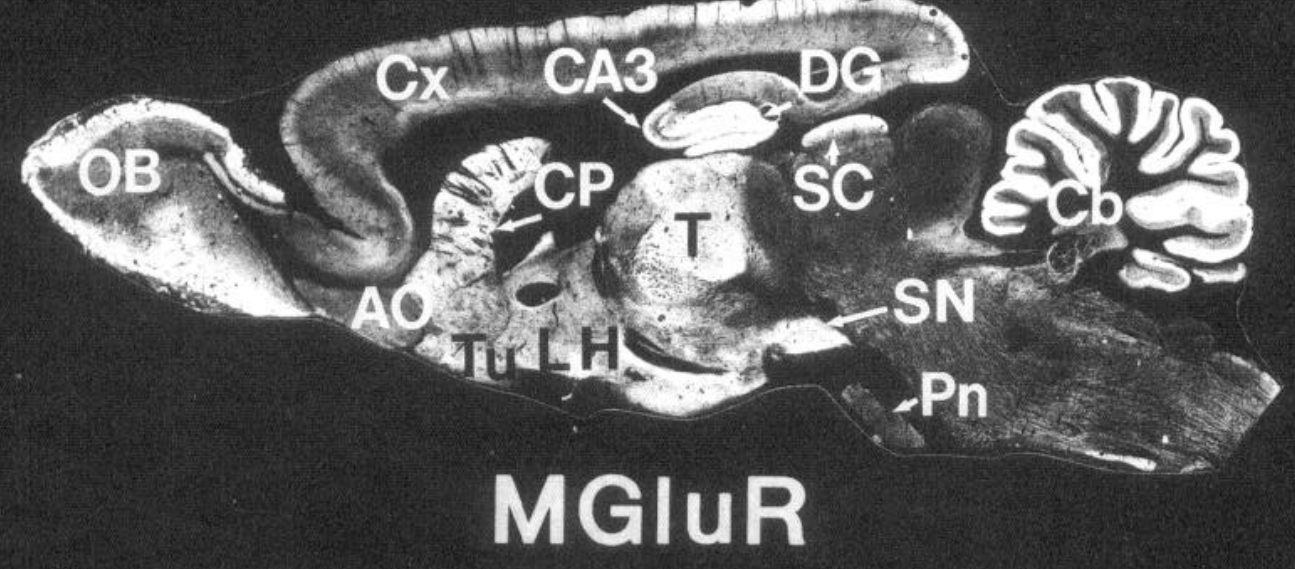

B

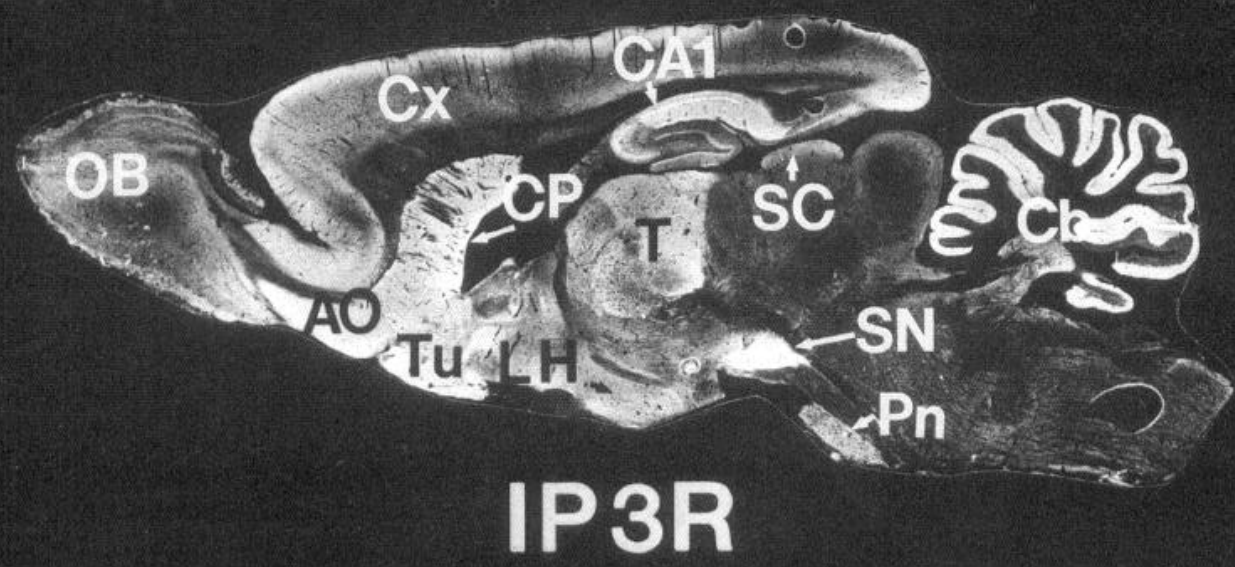

C

-

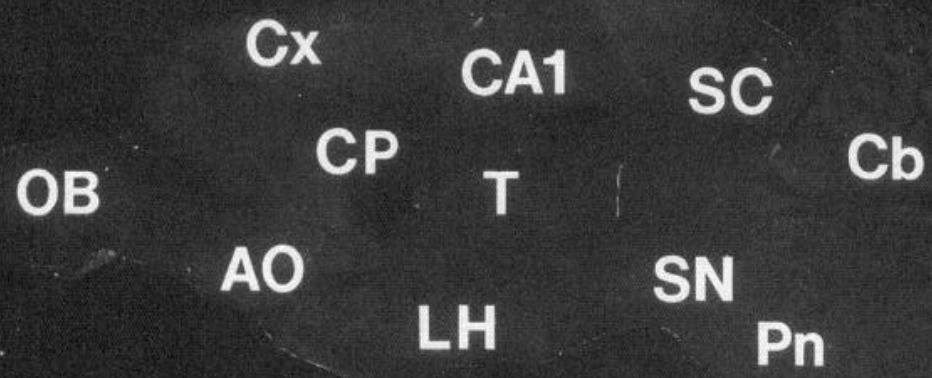

PA 


\section{MGluR IP3R MGIuR IP3R}

A
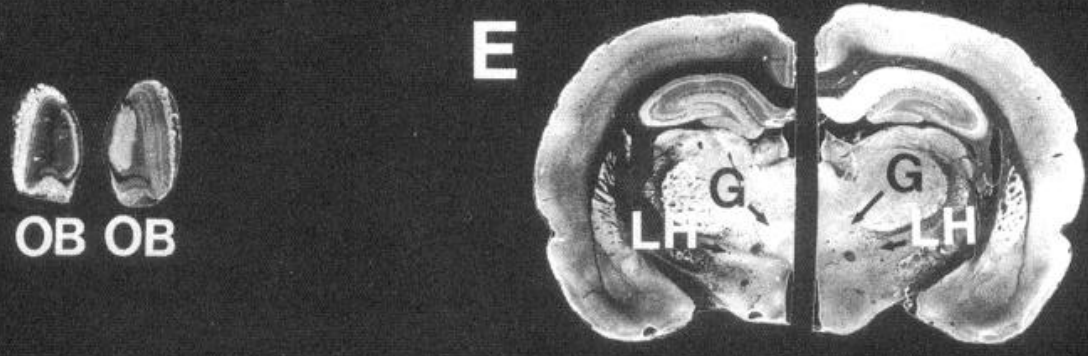

B

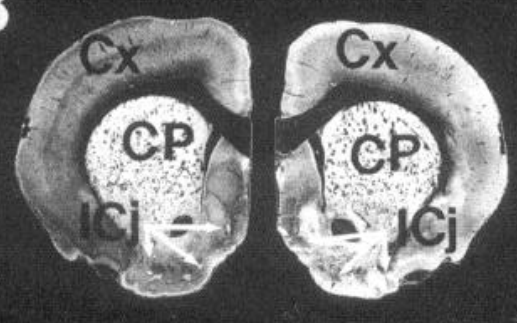

C

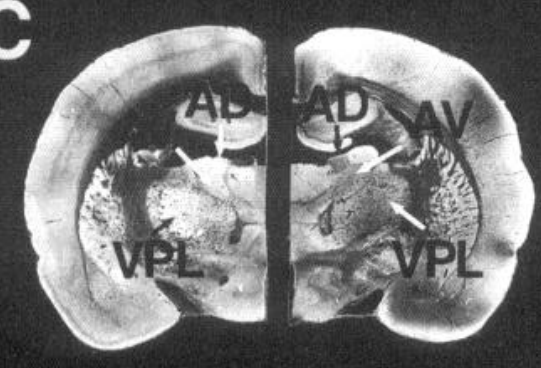

D

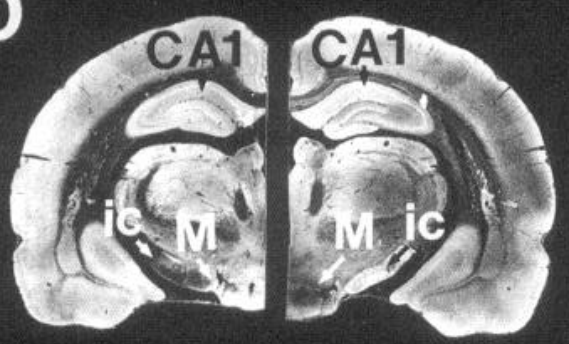

$\mathbf{F}$

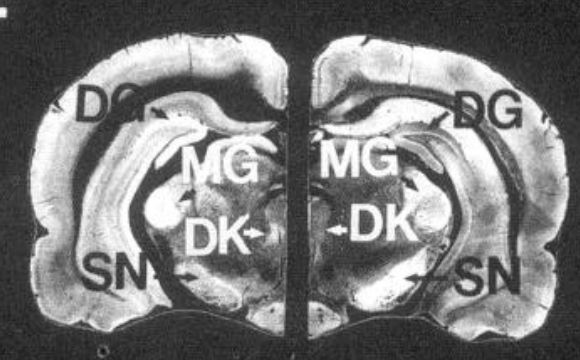

G

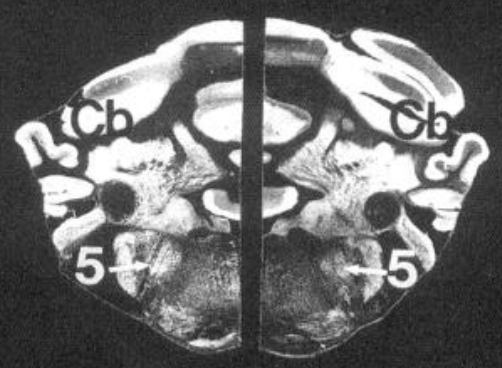

H 
MGluR
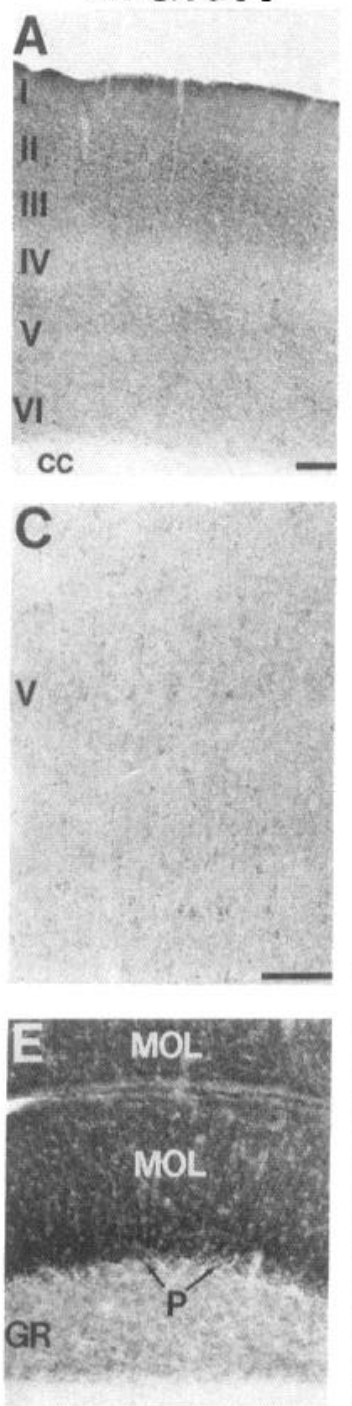

W
IP3R
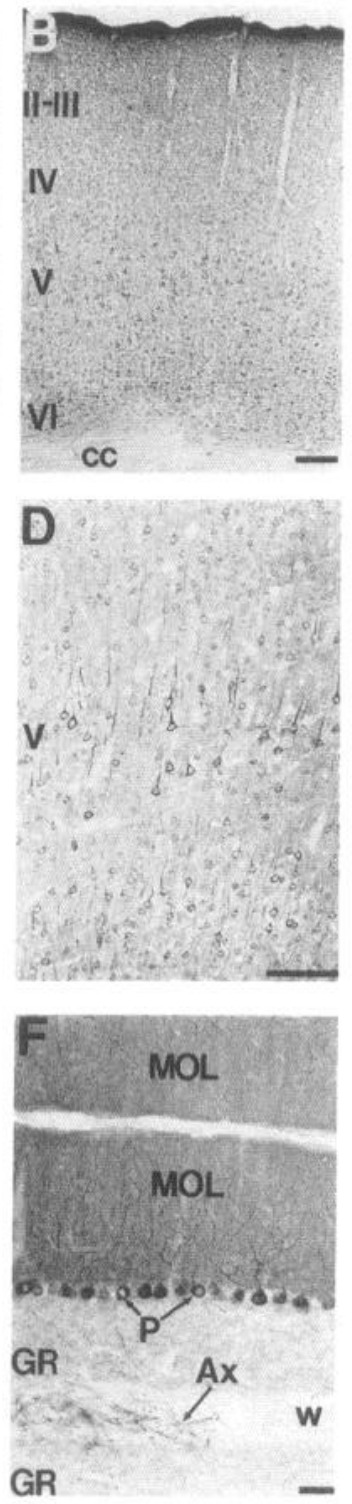

Figure 5. Contrasting localizations of mGluR 1 and $\mathrm{IP}_{3} \mathrm{R}$ immunoreactivity in the cerebral cortex and cerebellum. Adjacent sections were immunostained with mGluR 1 (left) and $\mathrm{IP}_{3} \mathrm{R}($ right) antibodies. mGluR 1 immunostaining is mostly in the neuropil as well as in the cell bodies of nonpyramidal cells enriched in layers II, III, V, and VI $(A, C) . \mathrm{IP}_{3} \mathrm{R}$ immunostaining differs from that of mGluR1 in being more concentrated in the cell bodies of pyramidal cells $(B, D)$. Neither antibody stains glia, as the corpus callosum $(c c)$ appears blank. In the cerebellum $(E, F)$, Purkinje cell bodies $(P)$ and their dendrites in the molecular layer $(M O L)$ both contain high levels of $\mathrm{mGluR} 1$ and $\mathrm{IP}_{3} \mathrm{R}$ immunoreactivity, though with somewhat different patterns. The granule cells $(G R)$, on the other hand, are enriched in mGluR 1 but lack $\mathrm{IP}_{3} \mathrm{R}$. As in the corpus callosum, the white matter $(w)$ of cerebellum is devoid of immunoreactivity. Axonal staining $(A x)$ appears in the white matter for $\mathrm{IP}_{3} \mathrm{R}$ but not for mGluR1. Scale bars, $100 \mu \mathrm{m}$.

aptic terminals in the caudate-putamen (Fig. 8), electrophysiological studies indicate that t-ACPD decreases synaptic excitation via presynaptic mechanisms, perhaps through inhibition of glutamate release (Baskys and Malenka, 1991; Lovinger, 1991). The ultrastructural localization of mGluR 1 in the striatum is interesting in light of the fact the PI-linked glutamate receptors were first identified in cultured striatal neurons (Sladeczek et

\begin{tabular}{|c|c|c|c|}
\hline & mGluRI & $\mathrm{IP}_{3} \mathrm{R}$ & PKC \\
\hline \multicolumn{4}{|l|}{ Olfactory bulb } \\
\hline External plexiform layer & 4 & 1 & 4 \\
\hline Mitral cell layer & 3 & 1 & 1 \\
\hline Anterior olfactory n. & 1 & 4 & 5 \\
\hline \multicolumn{4}{|l|}{ Basal ganglia } \\
\hline Caudate-putamen & 3 & 4 & 4 \\
\hline Globus pallidus & 3 & 1 & 1 \\
\hline Subthalamic n. & 4 & 0 & 0 \\
\hline \multicolumn{4}{|l|}{ Hippocampal formation } \\
\hline Stratum oriens CA1 & 4 & 2 & 5 \\
\hline Stratum oriens CA 3 & 4 & 2 & 4 \\
\hline Stratum radiatum $\mathrm{CA} 1$ & 0 & 4 & 5 \\
\hline Stratum radiatum $\mathrm{CA} 3$ & 2 & 1 & 3 \\
\hline \multicolumn{4}{|l|}{ Dentate gyrus } \\
\hline Granular cell layer & 1 & 3 & 2 \\
\hline Molecular cell layer & 4 & 1 & 4 \\
\hline \multicolumn{4}{|l|}{ Thalamus } \\
\hline Anterodorsal n. & 5 & 0 & 2 \\
\hline Anteroventral $\mathrm{n}$. & 4 & 1 & 3 \\
\hline Medial geniculate & 4 & 2 & 3 \\
\hline Gelatinosum n. & 3 & 1 & 1 \\
\hline \multicolumn{4}{|l|}{ Hypothalamus } \\
\hline Lateral $\mathrm{n}$. & 4 & 0 & 2 \\
\hline Mammillary $\mathrm{n}$. & 4 & 2 & 1 \\
\hline \multicolumn{4}{|l|}{ Cerebral cortex } \\
\hline Pyramidal cells & 0 & 4 & 4 \\
\hline Nonpyramidal cells & 3 & 1 & 1 \\
\hline \multicolumn{4}{|l|}{ Cerebellum } \\
\hline Molecular layer & 5 & 5 & 5 \\
\hline Granular cell layer & 3 & 0 & 1 \\
\hline Deep cerebellar $n$ & 3 & 2 & 3 \\
\hline \multicolumn{4}{|l|}{ Midbrain } \\
\hline Superior colliculus & 4 & 3 & 3 \\
\hline Red n. & 3 & 0 & 0 \\
\hline Substantia nigra & 2 & 4 & 4 \\
\hline Locus coeruleus & 1 & 3 & 2 \\
\hline Darkshevich's n. & 5 & 0 & 0 \\
\hline \multicolumn{4}{|l|}{ Cranial n. } \\
\hline Vestibular $\mathrm{n}$. & 4 & 1 & 1 \\
\hline Motor $\mathrm{n}$. of trigeminal & 3 & 1 & 1 \\
\hline Facial n. & 3 & 1 & 1 \\
\hline
\end{tabular}

The distribution of $\mathrm{mGluRl}$ corresponds to that of $\mathrm{IP}_{3} \mathrm{R}$ in some areas and to that of PKC in other areas. In some areas enriched in $\mathrm{mGluRl}$, high amounts of both $I_{3} R$ and $P K C$ are present, yet in other areas neither $I_{3} R$ nor PKC are detected. The values in mGluRI and $I_{3} R$ columns are from the immunohistochemical stainings presented here and range from lowest $(0)$ to highest $(5)$ based on visual inspection of the average of six sets of immunostaining experiments. The values for PKC are from Worley et al. (1986a,b, 1987; and M. Fotuhi, T. M. Dawson, and S. H. Snyder, unpublished observations).

al., 1985). Presumably these receptors are postsynaptic. Perhaps the ultrastructural localization of the novel PI-linked glutamate receptor (mGluR5) will be postsynaptic in striatum.

The present study shows substantial differences between the localizations of mGluRl and $\mathrm{IP}_{3} \mathrm{R}$ mRNA and protein. As mGluR 1 is believed to be linked to PI turnover, one might have expected its protein and mRNA to be distributed similarly to $\mathrm{IP}_{3} \mathrm{R}$. Instead, in numerous parts of the brain, we have observed a reciprocal localization of $m$ GluR 1 and $\mathrm{IP}_{3} \mathrm{R}$. In some areas, such as the islands of Calleja and anterodorsal nucleus of thal- 
MGluR
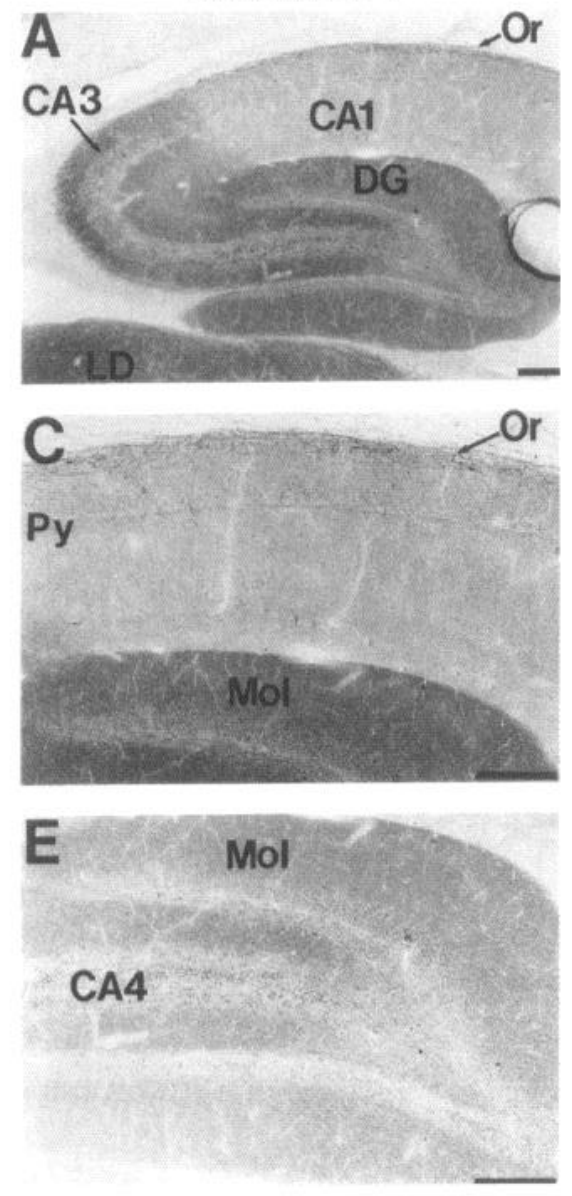

IP3R
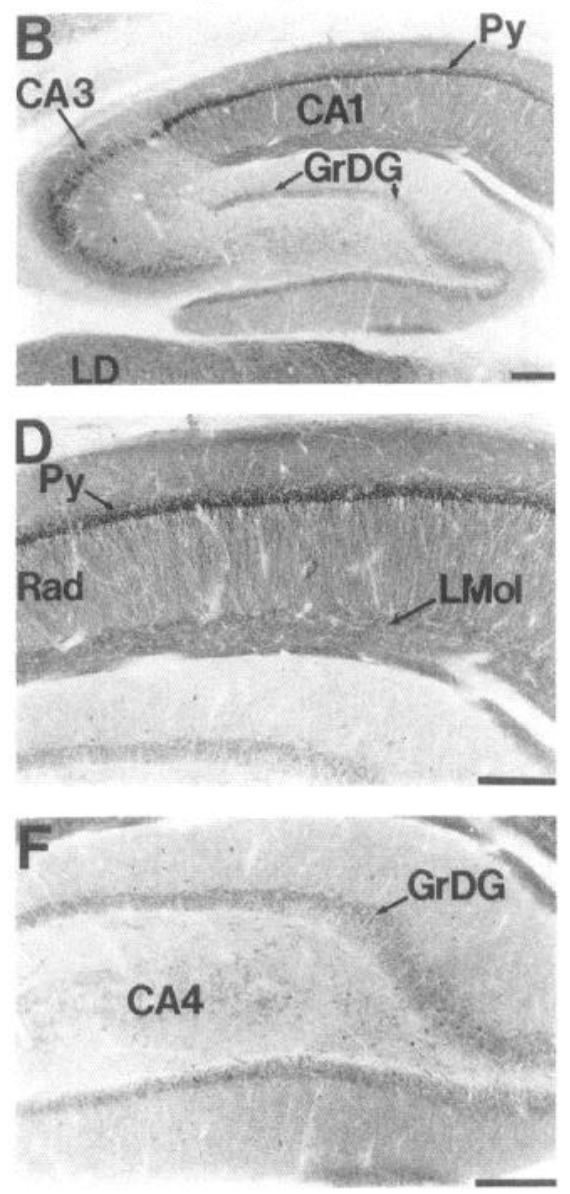

Figure 6. Reciprocal localizations of mGluR1 and $\mathrm{IP}_{3} \mathrm{R}$ immunoreactivity in the hippocampal formation. In these bright-field images of an adjacent pair of sections immunostained with mGluR1 (left) and $\mathrm{IP}_{3} \mathrm{R}$ (right) antibodies, dark areas represent positive staining. Stratum oriens of $C A 1$ and $C A 3$ $(O r$ in $A$ and $C$ ) and $C A 4$ contain an abundance of mGluR1-positive cells and processes in the absence of any appreciable $\mathrm{IP}_{3} \mathrm{R}$ immunostaining. The reverse occurs for pyramidal $(P y)$ cells and processes in stratum radiatum $(\mathrm{Rad})$ of CA1, the lacunosum molecular $(\mathrm{LMol})$, and granule cells of dentate gyrus $(G r D G)$. $L D$, lateral dorsal nucleus of thalamus; $D G$, dentate gyrus; $\mathrm{Mol}$, molecular layer of dentate gyrus. Scale bars, $100 \mu \mathrm{m}$. amus, we observe high levels of mGluR1 in the complete absence of $I_{3} R$. The PI cycle can be differentiated in terms of subtypes of PLC that have been selectively localized in the brain (Gerfen et al., 1988; Ross et al., 1989). Still, since the various forms of PLC all presumably generate $\mathrm{IP}_{3}$, one would not anticipate brain areas enriched in mGluRl but devoid of $\mathrm{IP}_{3} \mathrm{R}$. While other subtypes of $\operatorname{IP}_{3} R$ have been identified, they appear to be of much lower abundance than the form of IP ${ }_{3} R$ described here (Danoff et al., 1991; Nakagawa et al., 1991a,b; Südhof et al., 1991; Ross et al., 1992). However, the minor subtypes of $\mathrm{IP}_{3} \mathrm{R}$ may be concentrated in certain brain regions that more closely parallel the distribution of $\operatorname{mGluR} 1 \alpha$ and $\beta$. In such regions of dissociation of $m$ GluR 1 from $I_{3} R$, it is conceivable that $\mathrm{mGluR}$ acts through the PI cycle primarily to activate PKC. Several areas that are devoid of $\mathrm{IP}_{3} \mathrm{R}$ possess high levels of both mGluR1 and PKC (Table 1). Consistent with this possibility, quisqualate, which potently activates $\mathrm{mGluR}$, stimulates a rapid and transient translocation of PKC activity in striatal neurons (Manzoni et al., 1990). In addition, glutamate causes a transient phosphorylation of three PKC substrates in a time scale comparable to DAG production (Scholz and Palfrey, 1991).

Perhaps the distribution of mGluR5 may better fit with $\mathrm{IP}_{3} \mathrm{R}$ localizations in some brain regions. The existence of other subtypes of PI-linked mGluR as yet unidentified may also parallel the distribution $\mathrm{IP}_{3} \mathrm{R}$ better. For instance, in the molecular cloning studies, cross-hybridized cDNA clones were isolated from a cDNA library prepared from a certain size of mRNA (ap- proximately 3-4 kilonucleotides and greater than 4 kilonucleotides), and it is possible that a different size of cDNA may encode a distinct subtype of PI-linked mGluR. Furthermore, several groups have reported the possible existence of other subtypes of the PI-linked mGluR, such as the ibotenate-preferring mGluR (see Schoepp et al., 1990, for review).

We have also localized PI turnover by autoradiographical localization of ${ }^{3} \mathrm{H}$-CDP-DAG following the stimulation of mGluR 1 by $\mathrm{t}$-ACPD in the presence of ${ }^{3} \mathrm{H}$-cytidine. ${ }^{3} \mathrm{H}$-CDPDAG accumulation is a reliable technique for visualization of PI cycle as it is stoichiometrically linked to agonist-stimulated inositol formation (Godfrey, 1989; Hwang et al., 1990a,b; Kennedy et al., 1990). Similar to contrasting localization between mGluRl and $\mathrm{IP}_{3} \mathrm{R}$ immunoreactivities, there are discrepancies in t-ACPD-stimulated PI turnover, mGluR1, and $\mathrm{IP}_{3} \mathrm{R}$ immunoreactivity. For instance, ${ }^{3} \mathrm{H}-\mathrm{CDP}-\mathrm{DAG}$ accumulation and $\mathrm{mGluR} 1$ are high in the external plexiform layer of the olfactory bulb, where minimal amounts of $\mathrm{IP}_{3} \mathrm{R}$ are detected (Fig. 9). Moreover, t-ACPD-stimulated PI turnover and $\mathrm{IP}_{3} \mathrm{R}$ are low in the molecular layer of the dentate gyrus, where there are high levels of $\mathrm{mGluR} 1$ protein. Both these areas contain abundant amounts of PKC, suggesting that the actions of mGluR1 may be mediated through the PKC limb of the PI cycle. We also noted a lack of correlation of mGluR 1 protein levels as determined by Western blot analysis and t-ACPDstimulated PI turnover assessed by ${ }^{3} \mathrm{H}-\mathrm{CDP}-\mathrm{DAG}$. Similar results in the level of t-ACPD-stimulated PI turnover in various 
MGluR

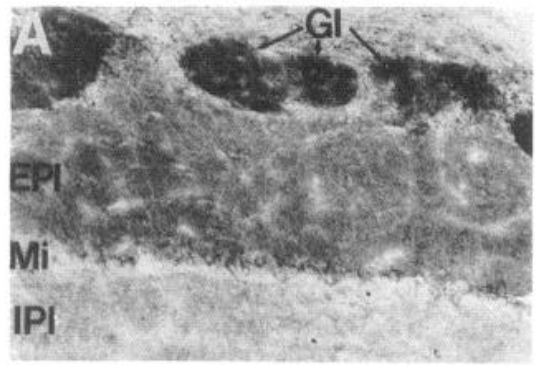
stained with mGluRI (left) and $\mathrm{IP}_{3} \mathrm{R}$ (right) antibodies. Positive staining appears as dark areas in these bright-field images. In the olfactory bulb $(A, B)$, mGluR 1 immunostaining appears dense in the glomeruli $(G l)$, in the external plexiform layer $(E P l)$, but low in the internal plexiform layer $(I P l)$. In contrast, the $\mathrm{IP}_{3} \mathrm{R}$ immunostaining is enriched in periglomeruli cells $(P G)$ and tufted cells $(T u f)$ in the mitral cell layer $(M i)$, where mGluR 1 protein level is low. In a pair of coronal sections $(C, D)$ through rostral striatum, seen at high magnification, islands of Calleja $(I C j)$ and olfactory tubercle $(T u)$ contain extremely high and low amounts of mGluR, respectively. The exact opposite occurs for $\mathrm{IP}_{3} \mathrm{R}$ immunoreactivity. Similarly, the arcuate nucleus $(A r C)$, the lateral hypothalamic nucleus $(L H)$, subthalamic nucleus $(S T h)$, dorsal perimammillary nucleus $(P M D)$, fornix $(f)$, and internal capsule (ic) exhibit reciprocal immunostaining for mGluR and $\mathrm{IP}_{3} \mathrm{R}$ proteins. $3 \mathrm{~V}$, third ventricle. Scale bar, $100 \mu \mathrm{m}$.
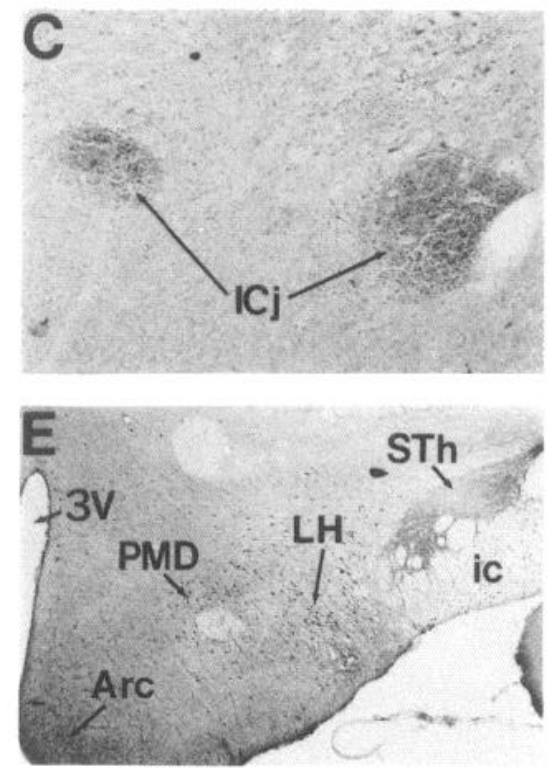

IP3R
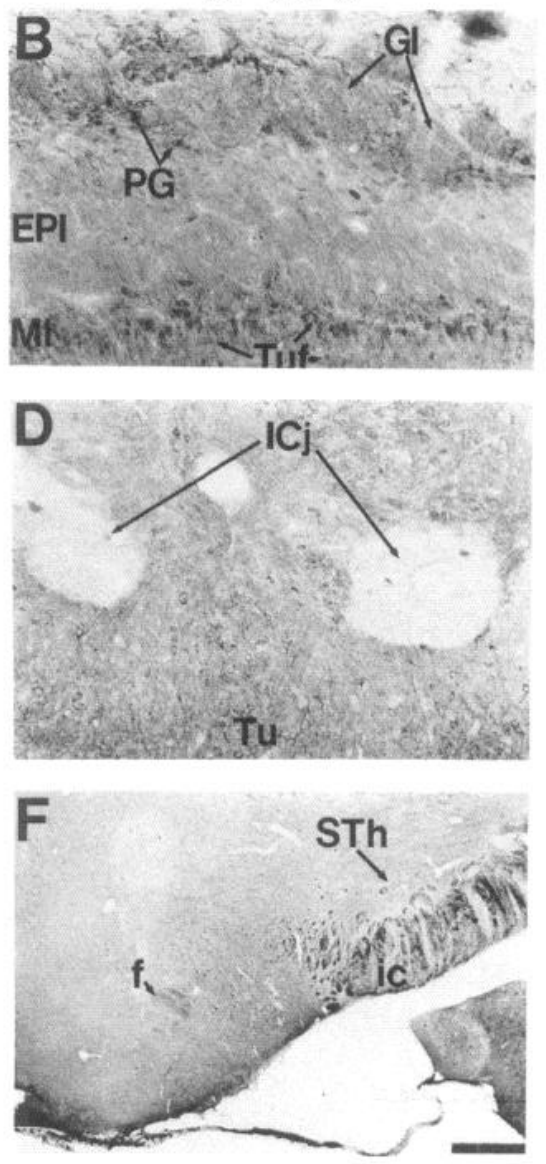

brain regions have been obtained by assessment of ${ }^{3} \mathrm{H}$-inositol phosphate accumulation, and there is also a marked discrepancy in these levels with the levels of mGluR 1 mRNA (Condorelli et al., 1992).

Together, these findings raise the possibility that mGluR 1 may act through the PI cycle to activate primarily $\mathrm{IP}_{3} \mathrm{R}$ or $\mathrm{PKC}$ depending on the relative distribution of the various components. Many other brain regions such as the subthalamic nucleus, red nucleus, and Darkshevich's nucleus are highly enriched in mGluR 1 but are devoid of both $\mathrm{IP}_{3} \mathrm{R}$ and $\mathrm{PKC}$, suggesting the possibility that mGluR 1 may also act through other second messengers. For instance, activation of phospho-
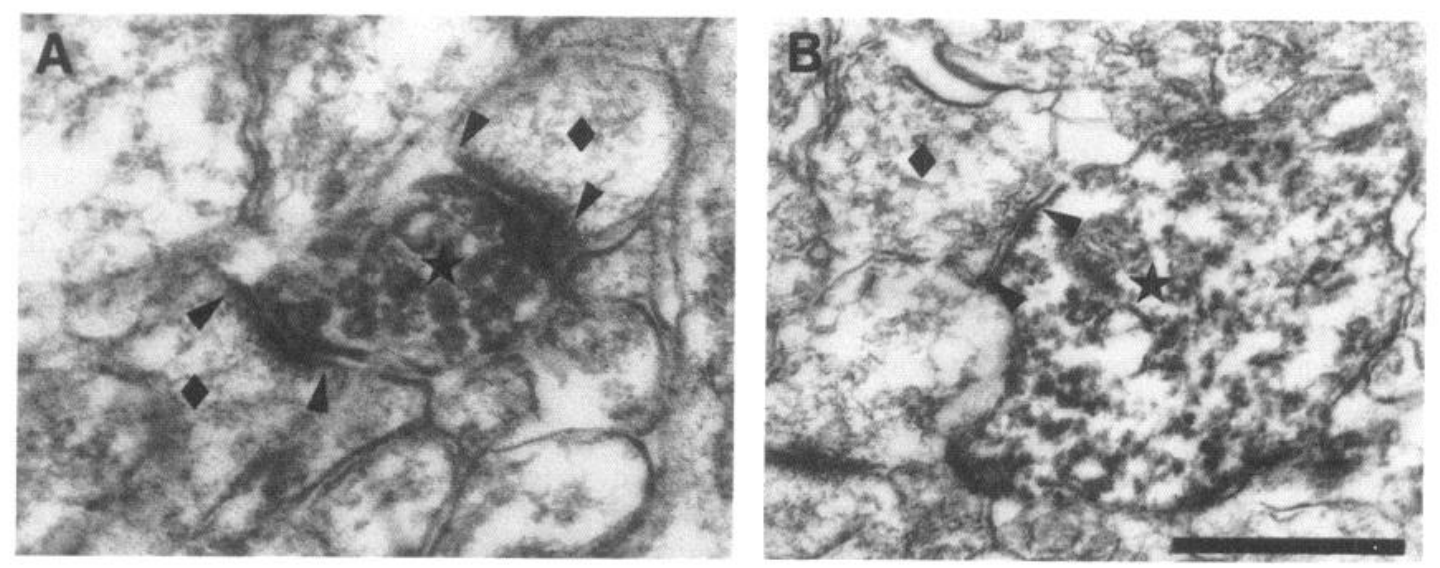

Figure 8. Contrasting localization of $\mathrm{mGluR} 1$ and $\mathrm{IP}_{3} \mathrm{R}$ viewed at the ultrastructural level. Electron micrographs show the pattern of $\mathrm{mGluR} 1-$ immunoreactive $(A)$ and $\mathrm{IP}_{3} \mathrm{R}$-immunoreactive $(B)$ structures. $A$ depicts mGluR 1 -immunoreactive terminal (star) forming an asymmetrical synaptic contact (region between arrowheads) with two postsynaptic structures (diamonds). B illustrates a dendrite containing $\mathbf{I P}_{3} \mathbf{R}$ immunoreactivity (star) receiving a synaptic contact (region between arrowheads) from a nonlabeled presynaptic terminal (diamond). Scale bar: $0.28 \mu \mathrm{m}$ for $A$; $0.5 \mu \mathrm{m}$ for $B$. 


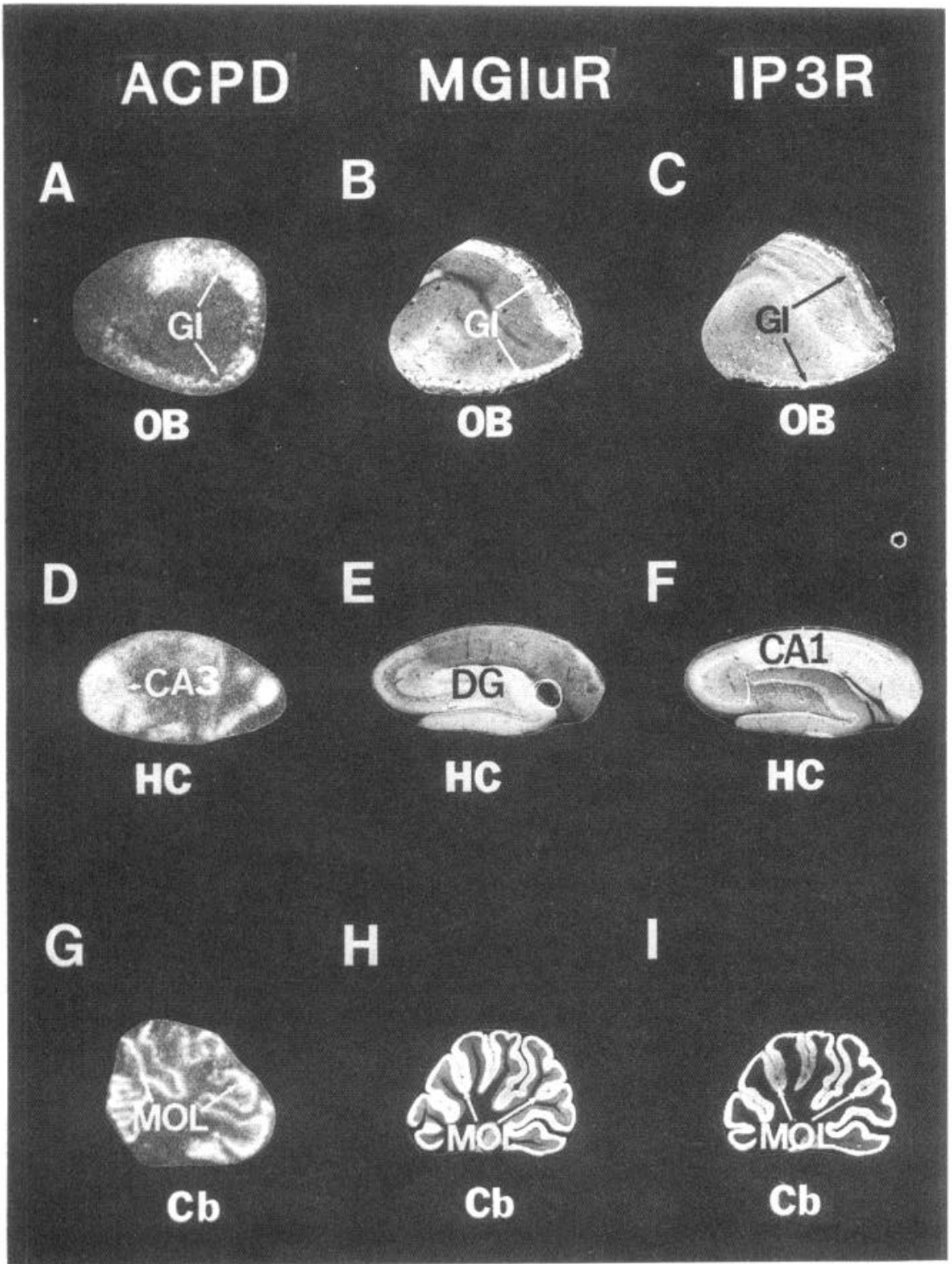

Figure 9. Comparison of the distribution of t-ACPD-stimulated PI imaging with the localization of mGluR 1 and $\mathrm{IP}_{3} \mathrm{R}$ immunostaining. $\mathrm{t}-\mathrm{ACPD}$ stimulated PI turnover $(A, D, G)$ occurs in parts of olfactory bulb $(O B)$, hippocampus $(\mathrm{HC})$, and cerebellum $(\mathrm{Cb})$ that contain high amounts of mGluR 1 immunostaining $(B, E, H)$ whether or not high amounts of $\mathrm{IP}_{3} \mathrm{R}$ immunostaining are also present $(C, F, I)$. PI imaging in $A, D$, and $G$ was carried out as described in the Materials and Methods. In the olfactory bulb $(A-C)$ PI imaging is concentrated in the glomeruli $(G l)$, which are also enriched in mGluR 1 but not in $\mathrm{IP}_{3} \mathrm{R}$ immunoreactivity. Similarly, in the hippocampus $(D-F)$, PI imaging is abundant in CA3 and stratum oriens of $\mathrm{CAl}$, regions that contain high and low amounts of mGluR 1 and $I P_{3} R$, respectively. Interestingly, t-ACPD-stimulated PI turnover is absent from the molecular layer of the dentate gyrus $(D G)$, an area with abundant mGluR 1 proteins. In the cerebellum $(G-I)$, however, PI imaging, mGluR 1 and $\mathrm{IP}_{3} \mathrm{R}$ proteins are all enriched in the molecular layer $(M O L)$.

lipase $\mathrm{A}_{2}\left(\mathrm{PLA}_{2}\right)$ and associated formation of arachidonic acid metabolites can involve G-protein-linked receptors (Piomelli and Greengard, 1990; Marin et al., 1991). Moreover, stimulation by mGluR agonists together with agonists of AMPA receptors enhances the formation of arachidonic acid in cultured striatal neurons (Dumuis et al., 1990). Whether this involves direct activation of $\mathrm{PLA}_{2}$ or DAG stimulation of $\mathrm{PLA}_{2}$ (Burch, 1988) awaits further study. The $N$-type calcium channel labeled by $\omega$-conotoxin (McEnery et al., 1991) is influenced by GTP derivatives and appears linked to G-proteins (Kasai, 1991). mGluR may be associated with a voltage-dependent calcium channel, as quisqualate in the presence of glutamate receptorgated ion channel antagonists can depress voltage-dependent $\mathrm{Ca}^{2+}$ currents in hippocampal neurons in culture in a G-proteindependent fashion (Lester and Jahr, 1990). The most convincing evidence for the association of other second messengers with mGluRl comes from Chinese hamster ovary cells expressing this receptor. In these cells, mGluR 1 agonists not only enhance PI turnover, but also stimulate the formation of cAMP and the release of arachidonic acid (Aramori and Nakanishi, 1992).

\section{References}

Abe T, Sugihara H, Nawa H, Shigemoto R, Mizuno N, Nakanishi S (1992) Molecular characterization of a novel metabotropic glutamate receptor mGluR5 coupled to inositol phosphate/Ca ${ }^{2+}$ signal transduction. J Biol Chem 267:13361-13368.

Aramori I, Nakanishi S (1992) Signal transduction and pharmacological characteristics of a metabotropic glutamate receptor, mGluR 1, in transfected CHO cells. Neuron 8:757-765.

Baskys A (1992) Metabotropic receptors and slow excitatory actions of glutamate agonists in the hippocampus. Trends Neurosci 15:9296.

Baskys A, Malenka RC (1991) Agonists at metabotropic glutamate receptors presynaptically inhibit EPSCs in neonatal rat hippocampus. J Physiol (Lond) 444:687-701.

Berridge MJ, Irvine RF (1989) Inositol phosphates and cell signalling. Nature 341:197-205.

Burch RM (1988) Diacylglycerol stimulates phospholipase $A_{2}$ from Swiss 3T3 fibroblasts. FEBS Letts 234:183-286.

Collingridge GL, Lester RAJ (1989) Excitatory amino acid receptors in the vertebrate central nervous system. Pharmacol Rev 40:145-210.

Condorelli DF, Dell Albani P, Casabona AG, Genazzani AA, Sortino MA, Nicoletti F (1992) Development profile of metabotropic glutamate receptor mRNA in rat brain. Mol Pharmacol 41:660-664. 
Danoff SK, Ferris CD, Donath C, Fischer G, Munemitsu S, Ullrich A, Snyder SH, Ross CA (1991) Inositol 1,4,5-trisphosphate receptors: distinct neuronal and non-neuronal forms derived by alternative splicing differ in phosphorylation. Proc Natl Acad Sci USA 88:29512955.

Dumuis A, Pin JP, Oomagari K, Sebben M, Bockaert J (1990) Arachidonic acid released from striatal neurons by joint stimulation of ionotropic and metabotropic quisqualate receptors. Nature 347:182184.

Ferris CD, Snyder SH (1992) Inositol 1,4,5-trisphosphate-activated calcium channels. Annu Rev Physiol 54:469-488.

Fotuhi M, Dawson TM, Sharp AH, Martin KJ, Graybiel AM, Snyder SH (1991) The phosphoinositide second messenger system is enriched in striosomes of the primate striatum. Soc Neurosci Abstr 17: 854.

Gerfen CR, Choi WC, Suh PG, Rhee SG (1988) Phospholipase C I and II brain isozymes: immunohistochemical localization in neuronal systems in rat brain. Proc Natl Acad Sci USA 85:3208-3212.

Godfrey PP (1989) Potentiation by lithium of CMP-phosphatidate formation in carbachol-stimulated rat cerebral-cortical slices and its reversal by myo-inositol. Biochem J 258:621-624.

Houamed KM, Kuijper JL, Gilbert TL, Haldeman BA, O'Hara PJ, Mulvihill ER, Almers W, Hagen FS (1991) Cloning, expression, and gene structure of a $G$ protein-coupled glutamate receptor from rat brain. Science 252:1318-1321.

Huang FL, Yoshida Y, Nakabayashi H, Young WS III, Huang K-P (1988) Immunocytochemical localization of protein kinase $\mathrm{C}$ isozymes in rat brain. J Neurosci 8:4734-4744.

Hwang PM, Bredt DS, Snyder SH (1990a) Autoradiographic imaging of phosphoinositide turnover in the brain. Science 249:802-804.

Hwang PM, Verma A, Bredt DS, Snyder SH (1990b) Localization of phosphatidylinositol signaling components in rat taste cells: role in bitter taste transduction. Proc Natl Acad Sci USA 87:7395-7399.

Kasai $H$ (1991) Tonic inhibition and rebound facilitation of a neuronal calcium channel by a GTP-binding protein. Proc Natl Acad Sci USA 88:8855-8859.

Kennedy ED, Challiss RAJ, Ragan CI, Nahorski SR (1990) Reduced inositol polyphosphate accumulation and inositol supply induced by lithium in stimulated cerebral cortex slices. Biochem J 267:781-786.

Lester RAJ, Jahr CE (1990) Quisqualate receptor-mediated depression of calcium currents in hippocampal ncurons. Neuron 4:741-749.

Lovinger DM (1991) Trans-1-aminocyclopentane-1,3-dicarboxylic acid (t-ACPD) decreases synaptic excitation in rat striatal slices through a presynaptic action. Neurosci Lett 129:17-21.

Manzoni OJJ, Finiels-Marlier F, Sassetti I, Blockaert J, le Peuch C, Sladeczek FAJ (1990) The glutamate receptor of the $Q_{p}$-type activates protein kinase $C$ and is regulated by protein kinase $C$. Neurosci Lett 109:146-151.

Marin P, Delumeau JC, Tence M, Cordier J, Glowinski J, Premont J (1991) Somatostatin potentiates the $\alpha_{1}$-adrenergic activation of phospholipase $C$ in striatal astrocytes through a mechanism involving arachidonic acid and glutamate. Proc Natl Acad Sci USA 88:90169020.

Martin LJ, Blackstone CD, Huganir RL, Price DL (1992) Cellular localization of a metabotropic glutamate receptor in rat brain. Ncuron 9:259-270.

Masu M, Tanabe Y, Tsuchida K, Shigemoto R and Nakanishi S (1991) Sequence and expression of a metabotropic glutamate receptor. Nature 349:760-765.

Mayer ML, Westbrook GL (1987) The physiology of excitatory amino acids in the vertebrate central nervous system. Prog Neurobiol 28: 197-276.

McEnery MW, Snowman AM, Sharp AH, Adams ME, Snyder SH (1991) Purified $\omega$-conotoxin GVIA receptor of rat brain resembles a dihydropyridine-sensitive L-type calcium channel. Proc Natl Acad Sci USA 88:11095-11099.

Miller RJ (1991a) Metabotropic excitatory amino acid receptors reveal their true colors. Trends Pharmacol Sci 12:365-367.

Miller RJ (1991b) The revenge of the kainate receptor. Trends Neurosci $11: 477-479$

Monaghan DT, Bridges RJ, Cotman CW (I989) The excitatory amino acid receptors: their classes, pharmacology, and distinct properties in the function of the central nervous system. Annu Rev Pharmacol Toxicol 29:365-402.
Nakagawa T, Okano H, Furuichi T, Aruga J, Mikoshiba K (1991a) The subtypes of the mouse inositol 1,4,5-trisphosphate receptor are expressed in tissue-specific and developmentally specific manner. Proc Natl Acad Sci USA 88:6244-6248.

Nakagawa T, Shiota C, Okano H, Mikoshiba K (1991b) Differential localization of alternative spliced transcripts encoding inositol 1,4,5trisphosphate receptors in mouse cerebellum and hippocampus: in situ hybridization study. J Neurochem 57:1807-1810.

Nakanishi S, Maeda N, Mikoshiba K (1991) Immunohistochemical localization of an inositol 1,4,5-triphosphate receptor, $\mathrm{P}_{400}$ in neural tissue: studies in developing and adult mouse brain. J Neurosci 11: 2075-2086.

Nicoletti F, Wroblewski JT, Fadda E, Costa E (1988) Pertussis toxin inhibits signal transduction at a specific metabotropic glutamate receptor in primary cultures of cerebellar granule cells. Neuropharmacology 27:551-556.

Nordquist DT, Kozak CA, Orr HT (1988) cDNA cloning and characterization of three genes uniquely expressed in cerebellum by Purkinje neurons. J Neurosci 8:4780-4789.

Peng Y-W, Sharp AH, Snyder SH, Yau K-W (1991) Localization of the inositol 1,4,5-trisphosphate receptor in synaptic terminals in the vertebrate retina. Neuron 6:525-531.

Piomelli D, Greengard P (1990) Lipoxygenase metabolites of arachidonic acid in neuronal transmembrane signalling. Trends Pharmacol Sci 11:367-373.

Ross CA, MacCumber MW, Glatt CE, Snyder SH (1989) Brain phospholipase C isozymes: differential mRNA localizations by in situ hybridization. Proc Natl Acad Sci USA 86:2923-2927.

Ross CA, Danoff SK, Schell MJ, Snyder SH, Ullrich A (1992) Novel inositol 1,4,5-trisphosphate receptors: molecular cloning and differential localization in brain and peripheral tissues. Proc Natl Acad Sci USA 89:4265-4269.

Saito N, Kikkawa U, Nishizuka T, Tanaka C (1988) Distribution of protein kinase C-like immunoreactive neurons in rat brain. J Neurosci 8:369-382.

Schoepp D, Bockaert J, Sladeczek F (1990) Pharmacological and functional characteristics of metabotropic excitatory amino acid receptors. Trends Pharmacol Sci 11:508-515.

Scholz WK, Palfrey HC (1991) Glutamate-stimulated protein phosphorylation in cultured hippocampal pyramidal neurons. J Neurosci 11:2422-2432.

Sharp AH, Dawson TM, Ross CA, Fotuhi M, Mourey RJ, Snyder SH (1992) Inositol 1,4,5-trisphosphate receptors: immunohistochemical localization to discrete areas of rat brain. Neuroscience, in press.

Sladeczek F, Pin J-P, Récasens M, Bockaert J, Weiss S (1985) Glutamate stimulates inositol phosphate formation in striatal neurons. Nature 317:717-719.

Südhof TC, Newton CL, Archer BT III, Mignery GA (1991) Structure of a novel InsP $\mathrm{P}_{3}$ receptor. EMBO J 10:3199-3206.

Tanabe Y, Masu M, Ishii T, Shigemoto R, Nakanishi S (1992) A family of metabotropic glutamate receptors. Neuron 8:169-179.

Worley PF, Baraban JM, DeSouza FB, Snyder SH (1986a) Mapping second messenger systems in the brain: differential localizations of adenylate cyclase and protein kinase C. Proc Natl Acad Sci USA 83: 4053-4057.

Worley PF, Baraban JM, Snyder SH (1986b) Heterogeneous localization of protein kinase $\mathrm{C}$ in rat brain: autoradiographic analysis of phorbol ester receptor binding. J Neurosci 6:199-207.

Worley PF, Baraban JM, Colvin JS, Snyder SH (1987) Inositol trisphosphate receptor localization in brain: variable stoichiometry with protein kinase C. Nature 325:159-161.

Worley PF, Baraban JM, Snyder SH (1989) Inositol 1,4,5-trisphosphate receptor binding: autoradiographic localization in rat brain. $\mathrm{J}$ Neurosci 9:339-346.

Yoshihara C, Saito N, Taniyama K, Tanaka C (1991) Differential localization of four subspecies of protein kinase $C$ in the rat striatum and substantia nigra. J Neurosci 11:690-700.

Young AB, Fagg GE (1990) Excitatory amino acid receptors in the brain: membrane binding and receptor autoradiographic approaches. In: The pharmacology of excitatory amino acids (Lodge D, Collingridge $\mathrm{G}$, eds), pp 18-24. Cambridge: Elsevier. 